\title{
Simultaneous Total Esophagectomy and Anterior Mediastinal Tracheostomy for Recurrent Laryngeal Cancer Extended to the Superior Mediastinum
}

\author{
Marius Fodor', Marcel Cosgarea ${ }^{2}$, Lucian Fodor ${ }^{3}$ \\ 'Department of General and Vascular Surgery, County Hospital, Cluj-Napoca, Romania \\ 2Department of ENT, County Hospital, Cluj-Napoca, Romania \\ ${ }^{3}$ Department of Plastic Surgery, County Hospital, Cluj-Napoca, Romania
}

Corresponding author:

Marius Fodor, MD, PhD

Department of General and Vascular

Surgery, County Hospital

Str. Clinicilor 1-3, 400006 Cluj-Napoca

Romania

E-mail: drfodor@yahoo.com

\section{Rezumat \\ Esofagectomia totală simultan cu traheostomia mediastinală anterioară pentru cancerul laringian recidivat extins în mediastinul superior}

Cancerul laringian recidivat are incidențã de 25-50\% şi ratã de supraviețuire la 5 ani de $23-35 \%$. Chirurgia este cel mai bun tratament pentru a realiza controlul local a recidivei tumorale. În acest articol, se prezintã strategia chirurgicalã în cazul unui pacient cu antecedente de laringectomie radical modificatã pentru cancer laringian şi cu recidivã tumoralã la nivelul traheostomiei extinsã la traheea toracicã şi la esofag. Timpul chirurgical de rezecție a inclus manubriul sternal, traheea toracicã superioarã, esofagul în totalitate şi limfoganglionii mediastinali superiori. Timpul chirurgical de reconstrucție a inclus traheostomia mediastinalã anterioarã şi esofagoplastia $\mathrm{cu}$ grefon colic pediculat simultan $\mathrm{cu}$ lamboul de pectoral mare pentru acoperirea defectului sternal.

Cuvinte cheie: cancer laringian recidivat, traheostomia mediastinalã anterioarã, esofagoplastia, grefon colic

\section{Abstract}

Recurrent laryngeal cancer has an incidence of $25-50 \%$ and a $23-35 \%$ fiveyear survival rate. Surgery is the best treatment in order to control local recurrence. Herein, we present our surgical strategy for a patient with a history of modified radical laryngectomy for laryngeal cancer and with recurrent tumor at the cervical tracheostomy site extended to the thoracic trachea and esophagus. The wide resection included the sternal manubrium, the upper thoracic trachea, the entire esophagus and the upper mediastinal lymph nodes. The reconstruction included anterior mediastinal tracheostomy and esophagoplasty with pedicled colonic graft simultaneously with pectoralis major flap for covering the sternal defect.

Key words: recurrent laryngeal cancer, anterior mediastinal tracheostomy, esophagoplasty, colonic graft 


\section{Introduction}

The incidence of recurrent laryngeal cancer ranges from $25 \%$ to $50 \%$ depending on primary location, tumor stage and previous therapy. Recurrent cancer has a five-year survival rate of only $23-35 \%$. The factors which improve the survival rate for recurrent laryngeal cancer are: early recurrence (stages I or II), long disease-free interval and no previous chemotherapy (1).

Goodwin et al (2) published a meta-analysis of recurrent laryngeal cancer that included 32 studies on 1633 patients treated by complex surgery and found a 2-year disease-free interval in $51 \%$ of patients and a 5 -year disease-free interval in $39 \%$ of patients. Surgery aims to control local recurrences and represents the best treatment for patients with recurrent laryngeal cancer.

Cancer recurrence at the tracheal stoma site represents an indication for anterior mediastinal tracheostomy (AMT) because the residual trachea is short after the resection of the cervical part. Morbidity after AMT ranges from 25\% to $70 \%$ despite recent progress $(3,4)$.

Recurrent laryngeal cancer extended to the thoracic esophagus represents an indication for transhiatal esophagectomy (THE) with esophagoplasty. Orringer et al (5) performed the first THE in 1976. Esophagectomy without thoracotomy reduced postoperative morbidity and mortality rates, thus proving to be a good surgical method. The reconstruction of the alimentary tract can be done with colonic, stomach and jejunal grafts $(6,7)$.

Herein, we describe our strategy for treating a patient with a history of modified radical laryngectomy for laryngeal cancer and with recurrent tumor at the cervical tracheostomy site extended to the thoracic trachea and esophagus.

\section{Case report}

A 54- year old man with T4NOM0 squamous cell carcinoma of the cervical tracheal stoma extended to the cervical and thoracic esophagus was admitted to our general surgery department. Seven years ago, the patient was diagnosed with laryngeal cancer treated by total laryngectomy with modified radical neck dissection and adjuvant radiotherapy. No chemotherapy was administered. The main complains were total dysphagia and cervical pain. Local examination showed hard tissue around the cervical tracheostomy, which extended $5 \mathrm{~cm}$ inward up to the $1 / 3$ proximal thoracic trachea (confirmed by direct endoscopy).
The biopsy revealed squamous cell carcinoma (Fig. 1A).

A CT scan with i.v. contrast revealed thickness of the cervical trachea wall extended to the thoracic trachea, the hypertrophic wall of the cervical esophagus extended to the thoracic esophagus up to T3 level and mediastinal vessel sparing with no mediastinal adenopathies (Fig. 1B).

Upper endoscopy showed a stenotic tumor at the pharyngoesophageal site and biopsy confirmed the presence of squamous cell carcinoma similar with the tracheal stoma biopsy. A nasogastric tube was placed for proper feeding. In these circumstances, the patient was referred to the oncology board, which recommended surgery as the first treatment.

Under general anesthesia with tracheal ventilation the surgical approach included:

A. Resection of $1 / 3$ upper sternum together with $1 / 3$ medial part of the clavicles, I and II ribs followed by wide resection of the cervical indurated skin, cervical trachea with $1 / 3$ upper thoracic trachea including the thyroid and parathyroid glands which were invaded by the tumor, the cervical esophagus and THE for thoracic esophagus (Fig. 1C). Frozen section was performed on the removed specimen and the result showed no presence of tumor cells. The lymph node dissection of the superior mediastinum was facilitated once the sternal manubrium was removed. (Fig. 1D)

B. Reconstruction included:

1) AMT after passing the residual trachea (1.5 cm length) below the brachial-cervical artery. The tracheal rings were sutured to thoracic skin. The ventilation tube was moved to the new tracheostomy.

2) Esophagoplasty with long pedicle colonic graft passed through the posterior mediastinum. Superiorly, it was sutured end-toend to the hypopharynx while the abdominal anastomosis was cologastric (end to side) on the posterior surface of the stomach. Both anastomoses were performed in double layers, separated stitches with PDS 3/0. (fig 2A). Simultaneously, pyloroplasty was performed. A nasojejunal tube was placed (tube passed the colonic graft, stomach, duodenum and stopped in the first jejunal loop).

3) The cervical soft tissue defect, the exposed great vessels and the colonic graft were covered with a pedicled pectoralis major 

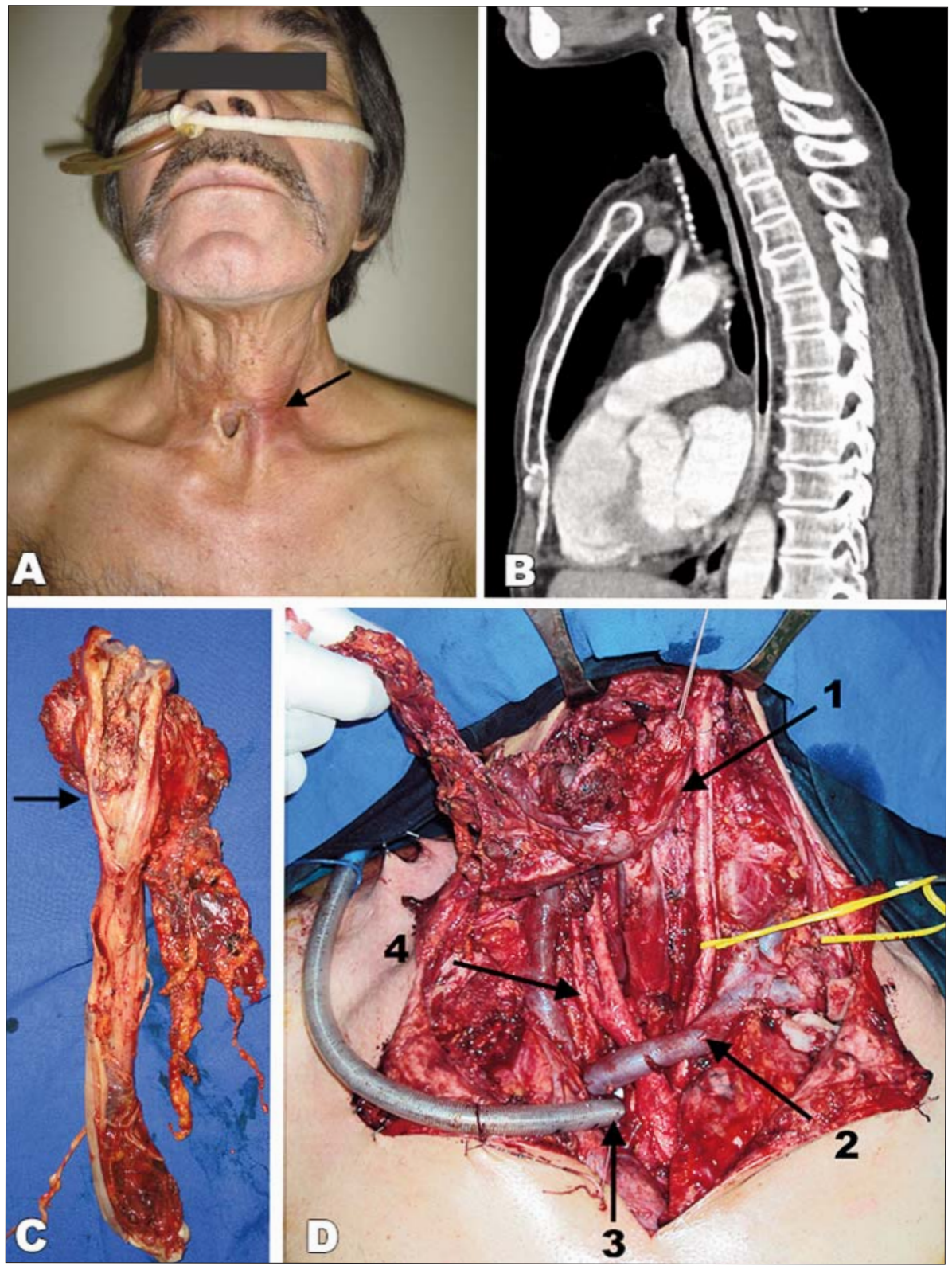

Figure 1. (A) Preoperative image: tumor recurrence (arrow); (B) Preoperative transversal CT scan;

(C) Resected specimen : tumor (arrow); (D) Wide resection of cervical trachea and thoracic esophagus: 1. Esophagus ; 2. Left brachial-cervical venous trunk; 3. Tracheal stump; 4. Brachial - cervical arterial trunk

musculocutaneous flap. A drainage tube was placed in the superior mediastinum. (Fig. 2B)

Postoperatively, the patient was transferred to the ICU. The following nasojejunal feeding protocol was used: saline solution $(50 \mathrm{ml} / \mathrm{h})$ for the first and second postoperative days followed by special nutrition solution for 3 weeks. On the 2nd day, a partial dehiscence on the superior portion of the mediastinal tracheostomy was observed. It was treated conservatively. On the 4 th postoperative day, the patient developed left hydrothorax treated by repeated puncturing drainage. The patient was ventilated for ten days through the mediastinal tracheostomy, after which he was able to breathe spontaneously without any signs of respiratory failure. On the 12th postoperative day, a right small pharyngocolonic fistula was noted on contrast media examination (Fig. 2C) and was treated conservatively. During this time, the patient was fed through the nasojejunal tube. The fistula closed after 10 days and the nasojejunal tube was 


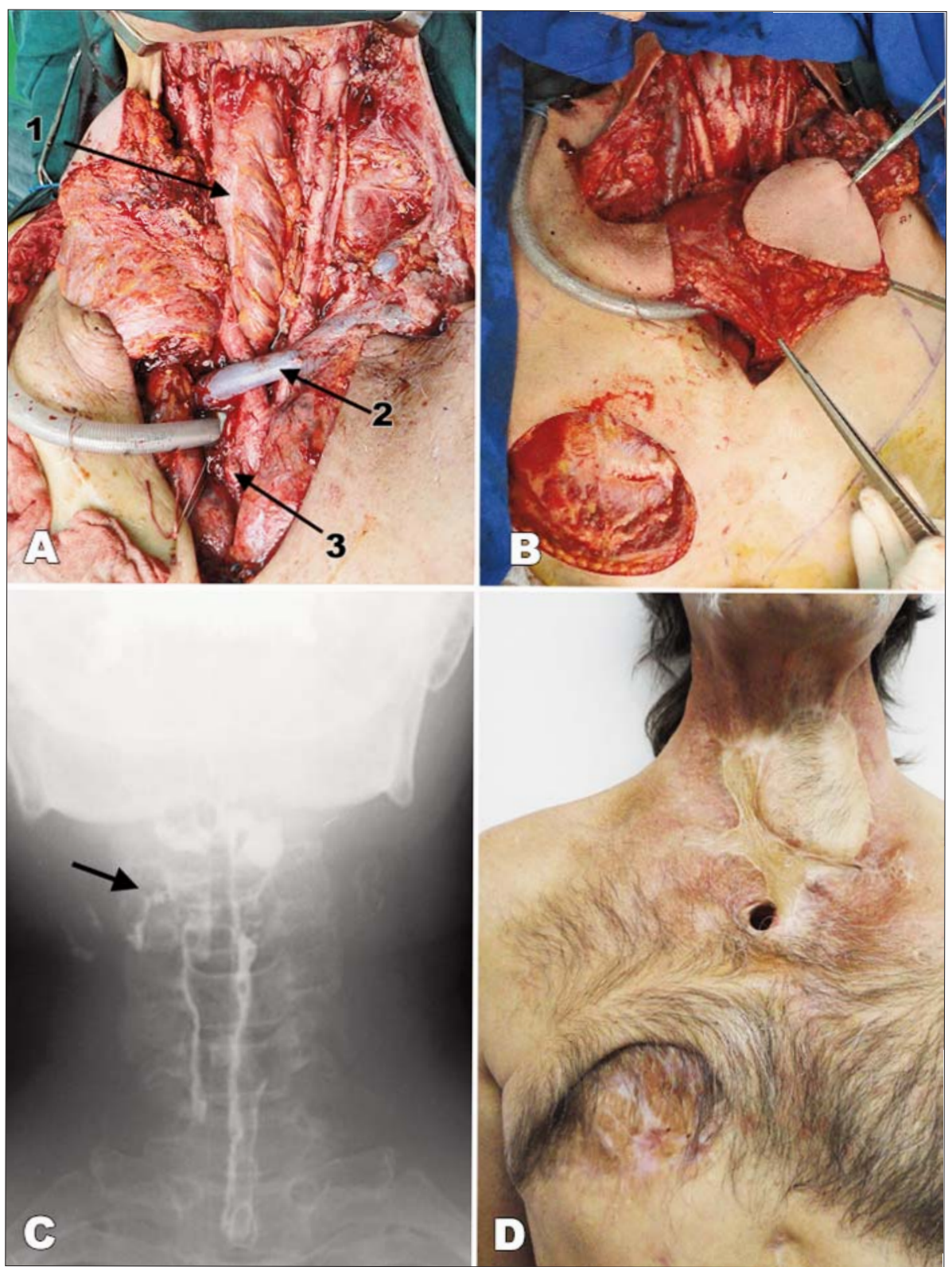

Figure 2. (A) Esophagoplasty with long colonic graft: 1.Colonic graft; 2. Left brachial-cervical venous trunk; 3. Tracheal stump; (B) Pedicled pectoralis major flap; (C) Contrast media passage: right pharyngocolonic fistula (arrow); D. Postoperative image after two years

removed, the patient being able to eat soft hypercaloric food.

On discharge, after 28 days in the hospital, the patient had functional AMT, a completely healed cervical wound and was able to self-feed.

He was prescribed specific treatment for postoperative thyroid and parathyroid insufficiency (euthyrox $50 \mathrm{mg} / \mathrm{day}$, calcium and alpha D3- 4 tablets/day).

We followed-up the patient and noted cervical lymphorrhea for 3 weeks. After surgery, the patient was referred to the oncology board, which recommended chemotherapy. The patient refused the adjuvant treatment.

The postoperative histopathological examination revealed that the squamous cell carcinoma of the cervical tracheal stoma extended to the thoracic trachea and to the cervical and superior thoracic esophagus with no metastasis in the upper mediastinal lymph nodes.

Two years after surgery, the patient has no sign of recurrence (Fig. 2D). 


\section{Discussion}

In our case of recurrent laryngeal cancer extended to the superior mediastinum (confirmed by direct tracheal endoscopy with biopsy), we rule out that the cervical esophageal cancer extended to the trachea due to postoperative radiotherapy (as a secondary cancer).

A review of the medical literature revealed a few studies concerning the simultaneous resection of the cervical trachea and esophagus for recurrent laryngeal cancer extended to the superior mediastinum (8). Most studies report cervical tracheal resection and AMT for neck cancers extended to the superior mediastinum (4).

Orringer et al (5) demonstrated that THE is the best method of treatment for carcinoma of the esophagus or other head and neck cancers invading the esophagus. Reconstruction of the digestive tract after extensive (cervical and thoracic) esophageal resection required, in our case, a long pedicled colonic graft (ascending, transverse, descending colon and part of the sigmoid colon with left colonic vessels) passed through the posterior mediastinum. It is mandatory to check the bleeding from the cervical part of the colonic graft to rule out distal colonic graft ischemia. When the cervical end of the colonic graft is not well vascularized, the microvascular anastomosis between colonic and cervical vessels is required in order to improve graft vascularization. Gastric pull-up for esophageal reconstruction after cervical and thoracic THE can be used, but we preferred the long colonic graft in order to reduce tension on the cervical anastomosis at the hypopharynx level and thus decrease the risk of anastomotic fistula (7). We performed pyloroplasty for duodenal drainage after vagal trunk resection, although some authors showed that this is not mandatory if the endoscopic method is used in case of postoperative post-vagotomy gastroparesis (6).

Although the incidence of fistulas in these cases is high, we noted a small fistula of the pharyngocolonic anastomosis. Usually, the incidence of minor anastomotic leaks rages from $11 \%$ to $16 \%$ and it requires conservative treatment (9).

AMT is the only solution after resection of the cervical trachea in patients with recurrent laryngeal cancer of the cervical tracheal stoma (10). Major complications of AMT include tracheal stump detachment, mediastinal infection and lesions of the great vessels $(3,4)$. In our case, we noted detachment between the pectoralis muscle flap and the tracheal stump in the superior portion of the AMT. The cause of this problem is stomal tension, which can be avoided by reducing the dead space in the upper part of the mediastinum as well as by placing the resected trachea below the brachial-cervical artery (BCA). We used a pedicled pectoralis musculocutaneous flap to cover the great vessels and to fill the dead space in the superior mediastinum. Some authors split the pectoralis muscle flap and wrap the tracheal stump (10). This was not possible in our case due to the small length of the tracheal stump. AMT with sternal manubrium and 1/3 medial costal resection could alter the respiratory function, especially in patients with anterior pulmonary disease (4). In our case, we did not observe acute or chronic respiratory failure.

\section{Conclusion}

Simultaneous AMT and total esophagectomy with esophageal coloplasty is a good surgical solution for the treatment of recurrent laryngeal cancer of the cervical tracheal stoma extended to the thoracic trachea and the cervicothoracic esophagus.

\section{References}

1. Ho AS, Kraus DH, Ganly I, Lee NY, Shah JP, Morris LG. Decision making in the management of recurrent head and neck cancer. Head Neck. 2014;36(1):144-51.

2. Goodwin WJ. Salvage surgery for patients with recurrent squamous cell carcinoma of the upper aerodigestive tract: when do the ends justify the means? Laryngoscope.2000;110(3):1-18.

3. Grillo HC. Development of tracheal surgery: a historical review. Part 1: Techniques of tracheal surgery. Ann Thorac Surg. 2003;75(2): 610-9.

4. Martinod E, Guillaume JY, Radu DM, Despreaux G. A more conservative technique for anterior mediastinal tracheostomy after sub-total resection of the trachea. Interact Cardiovasc Thorac Surg. 2011;12(5): 672-5.

5. Orringer MB, Marshall B, Chang AC, Lee J, Pickens A, Lau CL. Two thousand transhiatal esophagectomies: changing trends, lessons learned. Ann Surg. 2007;246(3):363-72.

6. Kesler KA, Pillai ST, Birdas TJ, Rieger KM, Okereke IC, Ceppa D, et al. "Supercharged" isoperistaltic colon interposition for long-segment esophageal reconstruction. Ann Thorac Surg. 2013;95(4):1162-8.

7. Matsuda T, Kaneda K, Takamatsu M, Takahashi M, Aishin K, Awazu M, et al. Reliable preparation of the gastric tube for cervical esophagogastrostomy after esophagectomy for esophageal cancer. Am J Surg. 2010;199(5):61-4.

8. Masuda M, Toriya $\mathrm{Y}$, Ihara $\mathrm{T}$, Abe R, Nagashima A, Komiyama S. Stomal recurrence invading the cervicothoracic esophagus and upper mediastinum: resectability and the creation of a safe anterior mediastinal tracheostoma. Eur Arch Otorhinolaryngol. 1999;256:70-2.

9. Yannopoulos P, Theodoridis P, Manes K. Esophagectomy without thoracotomy: 25 years of experience over 750 patients. Langenbecks Arch Surg.2009;394(4):611-6.

10. Fujita H, Kakegawa T, Yamana H, Shirouzu G, Minami T. Mediastinal tracheostomy using a pectoralis major myocutaneous flap after resection of carcinoma of the esophagus involving the proximal part of the trachea. Surg Gynecol Obstet.1990; 171(5):403-8. 